\title{
Stroke Therapy With Sensor Games Accelerometer And Gyroscope
}

\author{
Nur Trihadi Utomo \\ Department Of Electrical Engineering, University Of North Sumatra, Jl. Dr. Mansur No. 9 Padang Bulan, Kec. \\ Medan Baru, Kota Medan 20222
}

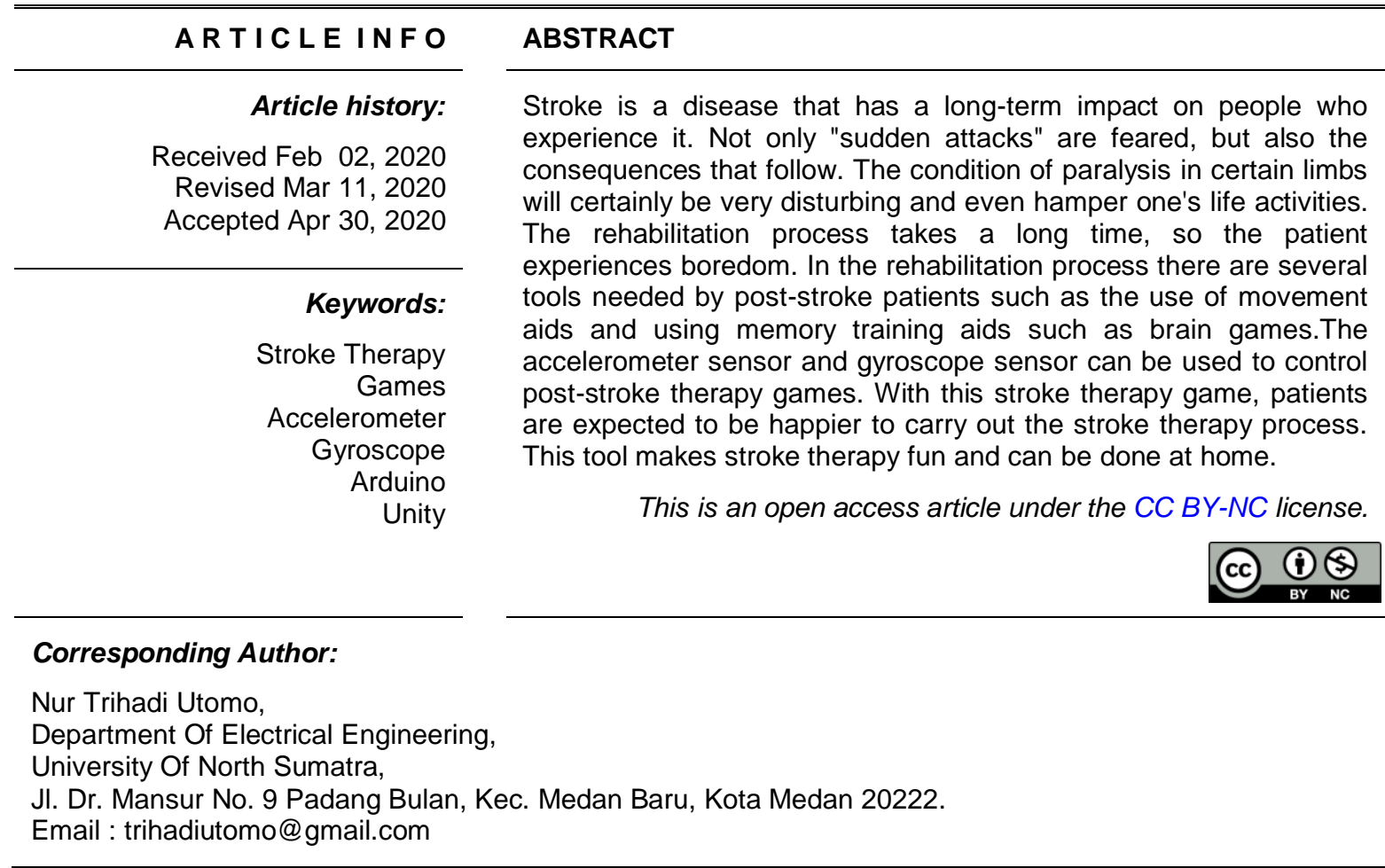

\section{INTRODUCTION}

Stroke is a disease that has a long-term impact on people who experience it. Not only "sudden attacks" are feared, but also the consequences that follow. The condition of paralysis in certain limbs will certainly be very disturbing and even hamper one's life activities.

Post-stroke patients require continued therapy to restore their physical condition. So that poststroke patients are recommended to follow the physical rehabilitation process. This rehabilitation process is urgently needed to restore the patient's condition as before, and improve the quality of life.

The rehabilitation process takes a long time, so the patient experiences boredom. In the rehabilitation process there are several tools needed by post-stroke patients such as the use of movement aids and using memory training aids such as brain games.

\section{RESEARCH METHOD}

The methods used in the analysis of writing this Final Project are as follows:

a. Literature study is by studying various references related to the above problems including studying Unity Engine, and Arduino Nano.

b. Stage control system design is to design a good control system used to be able to control 
games on Unity Engine.

c. Stage Testing is testing the system that has been designed by trying it whether the tool can function properly. Also, the preparation of the Final Project is to write a manuscript, in which it explains the theory used and the preparation of research reports that have been carried out.

\section{RESULTS AND DISCUSSIONS}

\subsection{Right Movement Test Results}

This test is a test that is carried out by moving the right hand, and trying to see if the tool with the game can work properly. This experiment was carried out 10 times. And the results are in table 1 as follows.

Table 1. right movement test

\begin{tabular}{ccc}
\hline & \multicolumn{2}{c}{ Results } \\
Test & Succeed & Fail \\
\hline 1 & $\sqrt{ }$ & \\
2 & $\sqrt{ }$ & \\
3 & $\sqrt{ }$ & \\
4 & $\sqrt{ }$ & \\
5 & $\sqrt{ }$ & \\
6 & $\sqrt{ }$ & \\
7 & $\sqrt{ }$ & \\
8 & $\sqrt{ }$ & \\
9 & $\sqrt{ }$ \\
10 & $\sqrt{ }$ \\
\hline
\end{tabular}

From table 1 it can be seen that there were no failures in this tool. When the tool is moved to the right, the player must turn to the right.

\subsection{Left Movement Test Results}

The test of this left movement is a test by moving the left hand. This test was also carried out 10 times. The results can be seen in table 2 as follows:

Table 2. left movement test

\begin{tabular}{|c|c|c|}
\hline \multirow[b]{2}{*}{ Test } & \multicolumn{2}{|c|}{ Results } \\
\hline & Succeed & Fail \\
\hline 1 & $\sqrt{ }$ & \\
\hline 2 & $\sqrt{ }$ & \\
\hline 3 & $\sqrt{ }$ & \\
\hline 4 & $\sqrt{ }$ & \\
\hline 5 & $\sqrt{ }$ & \\
\hline 6 & $\sqrt{ }$ & \\
\hline 7 & $\sqrt{ }$ & \\
\hline 8 & $\sqrt{ }$ & \\
\hline 9 & & $\sqrt{ }$ \\
\hline 10 & $\sqrt{ }$ & \\
\hline
\end{tabular}

From table 2, the failure occurred in experiment 9 . The failure that occurred was that the player did not respond to movement to the right.

\subsection{Jumping Movement Test Results}

This test is done by moving the hand up, the player will jump in the game. The results of this test can be seen in table 3 as follows.

Table 3. Move Jump Test

\begin{tabular}{cccc}
\hline Test & Succeed & Results & \\
& Fail \\
\hline 1 & $\sqrt{ }$ & \\
& $\sqrt{ }$ & \\
\hline
\end{tabular}




\begin{tabular}{ccc}
\hline 3 & $\sqrt{ }$ & \\
4 & $\sqrt{ }$ & \\
5 & $\sqrt{ }$ & $\sqrt{ }$ \\
6 & $\sqrt{ }$ & $\sqrt{ }$ \\
7 & $\sqrt{ }$ \\
8 & & \\
9 & $\sqrt{ }$ \\
10 & & \\
\hline
\end{tabular}

In this test, the failure occurred 2 times. That is on the 7th try and on the 9th try. The failure that occurred was that the player was too late to respond to the jump movement

\subsection{Right Tilt Movement Test}

This test is done by tilting the right hand. Its function is the same as moving the right hand, which makes the player move to the right.

Table 4. right-sloping test results

\begin{tabular}{ccc}
\hline Test & Succeed & Results \\
\hline 1 & $\sqrt{ }$ & \\
2 & $\sqrt{ }$ \\
3 & $\sqrt{ }$ \\
4 & $\sqrt{ }$ \\
5 & $\sqrt{ }$ \\
6 & $\sqrt{ }$ \\
7 & $\sqrt{ }$ \\
8 & $\sqrt{ }$ \\
9 & $\sqrt{ }$ \\
10 & $\sqrt{ }$ \\
\hline
\end{tabular}

\subsection{Test Results Tilt Left Movement}

This test is done by tilting the left hand. Its function is the same as moving the hand to the left, which is to make the player move to the left.

Tabel 5. Hasil Pengujian Miring Kekiri

\begin{tabular}{ccc}
\hline & & Results \\
Test & Succeed & Fail \\
\hline 1 & $\sqrt{ }$ & \\
2 & $\sqrt{ }$ & \\
3 & $\sqrt{ }$ & \\
4 & $\sqrt{ }$ \\
5 & $\sqrt{ }$ \\
6 & $\sqrt{ }$ \\
7 & $\sqrt{ }$ \\
8 & $\sqrt{ }$ \\
9 & $\sqrt{ }$ \\
10 & $\sqrt{ }$ \\
\hline
\end{tabular}

\subsection{Mid-Movement Test Results}

This test is done by keeping the hand in the middle. Its function is to keep the player in the middle.

Table 6. Mid-Movement Test Results

\begin{tabular}{clc}
\hline & & \multicolumn{2}{c}{ Results } \\
Test & Succeed & Fail \\
\hline 1 & $\sqrt{ }$ & \\
2 & $\sqrt{ }$ & \\
3 & $\sqrt{ }$ & \\
\hline
\end{tabular}




\begin{tabular}{cc}
\hline 4 & $\sqrt{ }$ \\
5 & $\sqrt{ }$ \\
6 & $\sqrt{ }$ \\
7 & $\sqrt{ }$ \\
8 & $\sqrt{ }$ \\
9 & $\sqrt{ }$ \\
10 & $\sqrt{ }$ \\
\hline
\end{tabular}

\subsection{Stroke Therapy Game Application Test}

This test is done by installing games that have been built from Unity. This test aims to determine whether the game can run on all PC specifications or only certain PCs that can run the game.

In application testing, the laptop used is an Axioo branded laptop with 8 GB RAM specifications and an Intel Core i3 processor. The operating system used is Windows 10. Figure 1 shows the results of the game application that was successfully run.

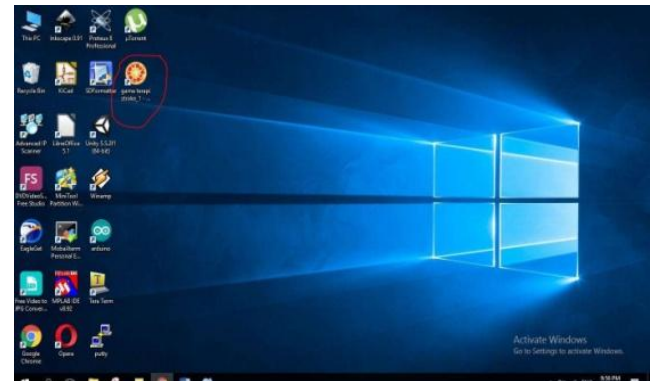

Figure 1. Display in Windows

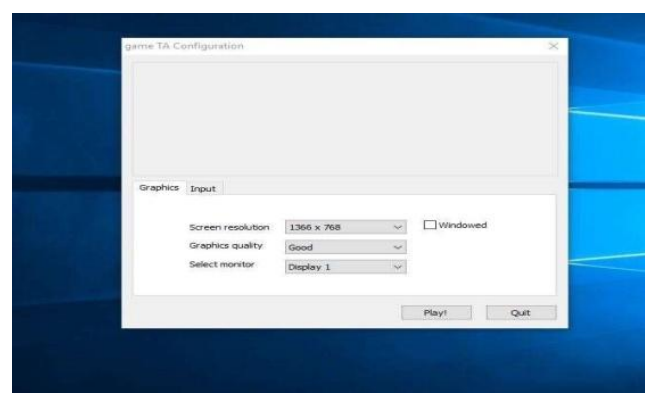

Figure 2. Game before run

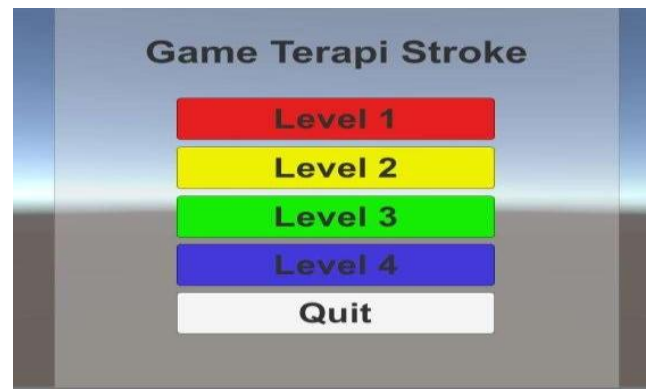

Figure 3. Game start 
Figure 1 shows the appearance of the application icon on the Windows desktop, and in Figure 3 shows the interface of the game application. On this interface page the user can choose what level he will start the game at. It is recommended to start from the lowest level to get used to playing the game and using the tool. While Figure 2 is the initial view when we click the game icon, then a page like Figure 2 appears. all we have to do is select play and the game will start and can be played.

\subsection{Testing on Different Types of Computer Specifications.}

To find out the applications that have been designed can run well on different computer specifications, the authors Perform testing on several computers. The results of this test are shown in table 7 as follows :

Table 7. Testing with different computer specifications

\begin{tabular}{ccc}
\hline No & PC/Laptop Specifications & Information \\
\hline 1 & Intel Core i3 RAM 8GB & Succeed \\
2 & AMD A8 RAM 4GB & Succeed \\
3 & Intel Core i5 RAM 4GB & Succeed \\
4 & Intel Atom 2GB RAM & Succeed \\
5 & AMD FX RAM 8GB & Succeed \\
\hline
\end{tabular}

On experiments for different specifications everything can be run. The highest specification I've ever tried is using an AMD FX processor laptop and 8GB RAM, and the lowest specification I've ever tried is an Intel Atom processor laptop and 2GB RAM.

\section{CONCLUSION}

Accelerometer and Gyroscope sensors can be applied to stroke therapy games. The author can make games that help post-stroke patients to undergo therapy. Failure in the jump attempt is a failure that occurs due to not sending data from Arduino. Or arduino does not respond when there is an upward movement of the hand.

\section{REFERENCES}

Alma'i Vidi rahman, 2011, "Aplikasi Sensor Accelerometer pada Deteksi Posisi". Jurnal Teknik Elektro UNDIP . http://eprints.undip.ac.id/25371, 16 July 2016

Mubarok Asep, 2013, "Pendeteksi Rotasi Menggunakan Gyroscope Berbasi Mikrokontroler ATmega8535". Jurnal Teknik Elektro Univesitas Diponogoro. 16 July 2016.

Accelerometer. Diakses Agustus 16, 2016, dari https://id.wikipedia.org/wiki/Accelerometer.

Riyadina Woro, Februari 2013, "Determinan Penyakit Stroke". Jurnal kesehatan Masyarakat Nasional. Volume 7, no. 7.

Sastri Susila, 2013, "Gambaran Faktor dan Tipe Stroke pada Pasien Rawat Inap di bagian Penyakit Dalam RSUD Kabupaten Solok Selatan". Jurnal Kesehatan Andalas. July 2016.

Gyroscope. Diakses Agustus 16, 2016, dari https://id.wikipedia.org/wiki/Gyroscope.

Dubey Sarthak,Dkk , 2013, " Semi-Automatic Continuous Passive Motion Physiotherapeutic Device for Post Stroke Patients". Jurnal IEEE.

Wahyudi, Februari 2012, "Calibration Method Of Rate-Gyroscope Sensor For IMU Rocket". Jurnal Teknologi Dirgantara. Volume 10, no.2.

Arduino. Diakses Agustus 16, 2016, dari https://id.wikipedia.org/wiki/Arduino.

Wahana Komputer. 2014. Mudah Membuat Game 3 Dimensi Menggunakan Unity 3D. Yogyakarta: Penerbit Andi.

Kadir Abdul. 2015. "Buku Pintar Pemrograman Arduino". Yogyakarta : MediaKom. 